\title{
窃盗犯の対象物選定時の危険性/容易性要因の役割に対する実験研究 一韓国の一般学生を対象とした模擬実験一

\author{
A EXPERIMENTAL STUDY ON THE ROLE OF RISK FACTOR \& EASE \\ FACTORS IN RESIDENTIAL BURGLARS' TARGET SELECTION
}

\author{
李 景 勳* \\ Kyung-Hoon LEE
}

\begin{abstract}
This study investigates the role of risk factors and ease factors in residential burglars' target selection process using a computer - simulated model. The results showed that burglars considered risk factor as the most important factor in target block searching and risk and ease factor were equally considered in target house searching. While the detailed risk and ease factors which affect burglars' target searching process are identified and the implications of these findings are considered, the limitations of the results are also discussed.
\end{abstract}

Keywords : Residential Burglary、Target Searching Process, Ease Factor, Risk Factor, Experimental Study 住居窃盜、対象物 探索過程、容易性要因、危険性要因、実験研究

\section{1. 研究目的と範囲}

大部分の犯罪者は犯行対象物を任意に選定せず、特に住居筇盗の ような財産犯罪の場合铂盜犯は合理的でありながら慎重に窃盗対象住宅 を選択する。従って住居窃盗予防対策樹立に一番重要なのは谽盗犯が 対象住宅を選定する時に影響を及ぼす環境の特性を明らかにすることだ。 それならば突盗犯は、何を基準しして穷盜の対象を選定するのか? 1980 年代以後、筇盜犯の対象物の探索及び選定過程に影響を及ぼす環境 特性に対する多様な研究が行われてきたが、こういった疑問はまだ様々な 部分が明らかにされぬまま残っている。

従って今回の研究では、こういった疑問を解決する為に窃盗犯の対象 住宅探索の過程を動映像によってシミュレーションしたモデルを使用し、(1) 窃盗犯が対象住宅を選定する過程で、段階別に影響を及ほす建築的特 性を明かにし、（2）此の様な特性にどのような要因が穷盗を誘発し、或い は抑制する役割を果たすかを明かにし窃盗犯が認識する各段階別に適切 な究盗対象物の一般的イメージ(template)の構造をより一層明確に究明 する。（3）最後には模擬実験を通して探索過程研究で動映像に依るシ ミュレーションという研究道具(research tool)の適切性を検証する。

\section{2. 探索過程に対する理論的考察}

伝統的な犯罪学での、少数の犯罪者的な属性を持った人達に因って 犯罪が発生すると仮定した場合、ある心理, 社会, 経済的な要因がそう いった犯罪者的な属性に影響を与えるかという事を説明しようと努力した。 反面1980 年代以降に現れた、合理的な選択理論や日常行為的な 理論等「状況的な接近（situational approach）」では、犯罪は少数 の犯罪者的な属性を持った人に因ってのみ行われる事では無く、切実な金
銭面での必要性等の圧力と制約を受ける状態で、容易に犯罪を犯せれる 機会を提供する状況にぶつかれば、平常時極めて正常で合法的な生活 をする人でも犯罪行為を犯寸可能性もあるという事を前提にした。即ち犯罪 の機会を提供する、状況的な要因の役割を強調している。また、大部分 の人がショッピング等の日常行為で経済性と合理性に基づく選択をするよう に、犯罪もやはりそれに伴う費用(cost)と利益(reward)を比較して犯行の 可否を判断するが、こういった決定を下すのに環境的な特性が大変重要 な役割をするという事を主張する。

BrantinghamとBrantingahm(1978)の対象物選定理論で、犯罪行 為は、地域、ブロック、そして個別住居が提供する各段階別の環境特性 に対する犯罪者の連続的判断の結果として規定される。多段階で成され る探索過程で犯罪者は、各段階の環境が提示する環境特性を通し、費 用一報償間の理性的比較をする事に依って、合理的に対象物を選定する という事になる。従って、図1で見るように様々な対象地域の中で特定地 域を選定し、地域の内の様々な対象ブロック中で特定ブロックを選定し、 ブロック内の対象住宅の中で特定住宅を選定するのだが、このような決定 は完全に各段階の環境特性が铂盗遂行に適切かどうかに対する资盗犯 の合理的判断根拠があると見られる。此の様な環境特性の適切性に対 する経験的知識が增す程どのような環境特性が“適切な”対象物を意味す るかを学ぶようになるのである。此の様な過程を通して、铹盗は「適切な 犯行対象物の一般化されたイメージ」(テンプレイト)を持つようになり、一 旦テンプレイトが構築されると相省部分が固定し、その後の探索及び意思 決定過程では、持続的に利用されるのである。

窃盗犯のテンプレイトを構成する環境特性は大きく（1）報償要因 (reward factor)と (2) 費用要因(cost factor)とに゙分けられ、その中で 


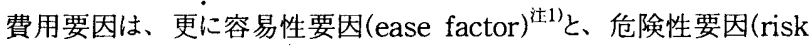

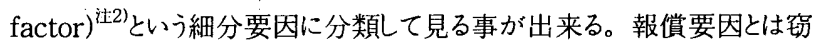
盗を遂行する結果で得られる経済的代価を表し、同一な費用を投資して 利益を極大化しようするすべての合理的行為の本来の目標のように、窃 盗犯もまた状況が許する限度内で自身の犯罪行為に対する最大限の代 価を求める。しかし、報償要因とは建築計画的に統制できない部分であ り、報償要因が同二であると仮定する場合、結局窃盗遂行の可否に対 する決定は、容易性要因と伦険性要因の間の比較(balancing)に依って 決定される(図2参照)。従って窃盗犯のテンプレイト 中の容易性要因に該 当する特性が何で危険性要因に該当する特性が何であるのか、明確に 究明されれば建築計画時の容易性要因を最小化させ危険性要因は極大 化させる事によって潜在的窃盗犯の筇盗遂行の意図を萎縮させることがで きるはずだ。しかし、不幸にも䥼盗犯の探索過程を直接扱う研究に対し多 くの研究者の関心をひくことができなかったが、これは、窃盗犯の探索過 程に対する研究方法自体に現実的な難しさが多いという点が、大部分の 起因である。探索過程に対する研究(Bennet、1986; Rengert \& Wasilchick、1988; Taylor \& Nee、1988; Walsh、1986)は大概、 少数の起訴された筇盜犯を対象とした深層インタビュー、又は、一般人 や窃盗犯に図面、写真、スライド、ビデオテープ等で、模写された環 境を表し、窃盗遂行の意思を問う方式を使用した二つの部類に分類でき るのだが、前者は厳格な仮説検証に適する研究方法ではなく、後者の場 合、仮説検証は可能だが模写された環境自体の妥当性(validity)問題 に対する批判を受けてきた。実際探索過程で锶盗犯はべルを押して人の 存在可否を確認してみる等積極的探索をしてみたり、街灯を割る等の窃盗 に有利な環境を造り出す努力をしたりする。従って、図面、写真、スラ 价及びビデオテープ等を通し、制限された情報を一方的に提供する既存 の研究方法は、実際の铂盗犯の探索過程を十分に模写できないという問 題点をかかえている。

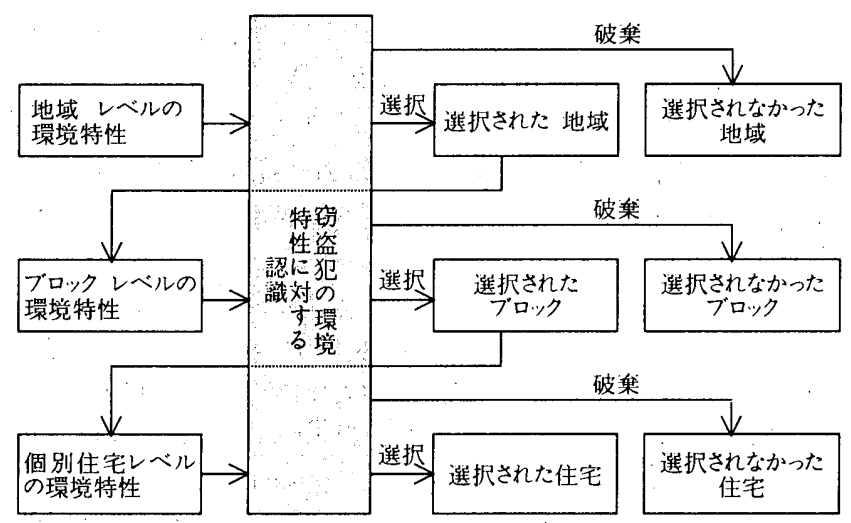

図1. 㫟盗犯の対象物選定過程

\begin{tabular}{|c|c|c|c|c|c|}
\hline \multirow{3}{*}{$\begin{array}{l}\text { 被 } \\
\text { 害 } \\
\text { 詨 } \\
\text { 象 } \\
\text { 物 } \\
\text { の } \\
\text { 特 } \\
\text { 性 }\end{array}$} & \multirow{2}{*}{$\begin{array}{l}\text { 建築的 } \\
\text { 特性 }\end{array}$} & \multicolumn{2}{|c|}{$\begin{array}{l}\text { 報償要因 } \\
\text { (reward) }\end{array}$} & \multirow{3}{*}{ 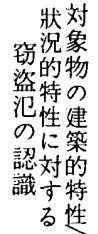 } & \multirow{3}{*}{ 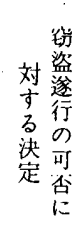 } \\
\hline & & \multirow{2}{*}{$\begin{array}{l}\text { 費用要因 } \\
\text { (cost) }\end{array}$} & 容易性要因 & & \\
\hline & & & 他険性要因 & & \\
\hline
\end{tabular}

困2. 住居䉈盜犯の対象物選定テンプレイトの特性

\section{3. 研究方法と実験の順序}

3.1. 本研究で使用されたシミュレーションモデルの特性

本研究では前に述べた既存研究方法の問題点を改善するために動映
像を利用し、探索過程シミュレーションモデルを開発使用したのだが、開 発されたモデルの特徵は次の通りである。先ず、シミュレーションモデル は、ブロック探索過程モデルと個別住宅の探索過程モデルの2つの段階 に区分される。此の様にブロック探索過程と個別住宅の探索過程を2段階 に分離してもデル化したのは、前に述べた様に攽盗犯が対象物を選定す るに於いて、広範囲な地域の選定からブロック選定そして、個別住宅の 選定に至るまでの各段階別過程を経ながら、各段階で考慮される変数が お互いに違うと判断された為である。二つに制限された範囲ではあるが、 双方向的な動映像シミュレーションモデルを開発して使用した。開発された 探索過程の動映像シシュレーションモデルは、実際に窃盗犯が対象物を 選定する為に探索過程と最大限類似するように、人間の視点の歩行速度 で動きながらブロック内の各住宅を観察する一連の連続的過程を動映像 で見せる様になっている。観察過程で特別に関心を引く住宅がある場 合、動映像画面(図3参照)右側上端のブロック内の住宅配置図で求める 住宅を選択すればそれぞれ異なった力向で該当住宅を見せてくれる、二 つの停止画面が画面の右側下端にあらわれるようにした従って、該少住 宅を実験対象者が望む方向や距離から、一方的に選択して観察するの は、技術的な問題なので不可能ではあるが、制限された範囲内で望む ，住宅に対し、より精密な観察を選択し得る双方向性を持つモデルを構築す る事に依って、既存のシミュレーション方式で提起された妥少性の問題を 大き向上させる事が出来る。最後に、本モデルは実在する建築環境で はなく、任意に創造された仮想のシミュレーションモデルである。従って、 探索過程が現場訪問なしに実験室で成される為、時間と費用が節約さ れ、実験を目的に創造された仮想の環境なので、実際環境が露出される 為に伴う法的・倫理的問題から解放される。又、研究者が願う環境を任 意で創造し得るので、変数を多用に組み合せたモデルを構成して、別の 変因を一定部分統制した状態で求めた分析変数の影響力を検証する事 が出来る。

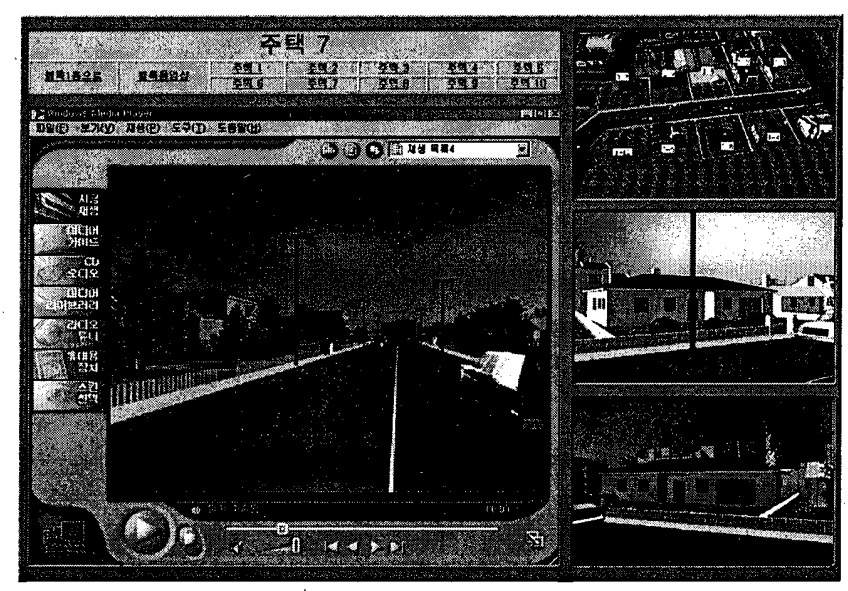

図3. 探索過程動映像及び精密探索画面

\section{2. 分析変数の測定及び関連仮説}

本研究で1個の従属变数(苆盗被害確率)と13個の独立変数が使用さ れたが、独立変数は更にブロック関連变数(3個)と個別住宅の関連変数 (10個)とに区分される(表1参照)。独立変数は皆、窃盗に有利な状況

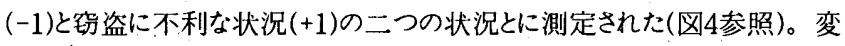
数の内、客観的に評価し難い 4 個の変数(建物形態、建物色彩、富の

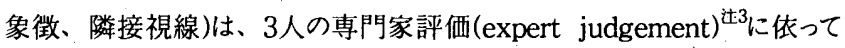
決定された。又、従属变数である住宅別窃盗被害の確率は、可能な応 答の総頻度数中、該少する住宅が実際に選択された頻度数の百分率

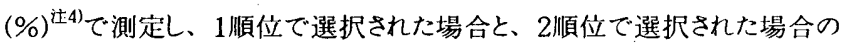


加重値を各々差をつけて定めた。

独立変数は、危険性要因、容易性要因、報償要因の中で、最小 限1個以上の要因に対する仮説と関連する(表1参照)。一例として隣接視 線変数の場合、隣の家で容易に見る事が出来る場合、穷盗犯が窃盗 途中隣の家の視線に依って、発覚される伦険性を增大させる為に危険性 要因と関連し: 防犯空枠の設置可否変数は、防犯空枠が設置されな かった場合に侵入の容易さを増大させる為、容易性要因と関連するので ある。しかし、塀の高さと同じ一部の変数は同時に二つの要因と関連され るが、一例として型が高いというのは、道路や隣接住宅から該省住宅を 監視するのを難かしくする為、発覚の危険性を減らす事が出来る。一方 では、弪盜犯の物理的侵入を難しくして容易性を落とす側面を同時に持っ ている。このようにその要因が明確ではなく、一部変数に対しては被験者 達が危険性要因と容易性要因の中でどんな要因に比重を置いて判断する かを見る為、2つの仮説を同時に設定した。

\section{表1. 分析変数と関連した伋説及び測定方法}

\begin{tabular}{|c|c|c|c|c|c|c|}
\hline \multirow{2}{*}{\multicolumn{2}{|c|}{ HPTy }} & \multicolumn{3}{|c|}{ 阅速使喅 } & \multicolumn{2}{|c|}{ 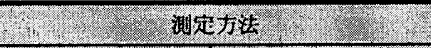 } \\
\hline & & 容 & 俩 & 新 & 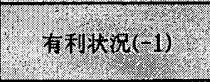 & 不利状织( $(+1)$ \\
\hline$\frac{1}{3 x}$ & 铂沁被害確率 & & & & \multicolumn{2}{|c|}{ 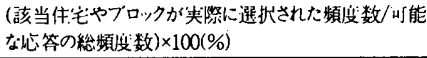 } \\
\hline \multirow{3}{*}{ 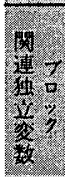 } & 連結道路数 & - & - & & $\begin{array}{l}\text { プロック連結道路数が } \\
\text { 多い }\end{array}$ & $\begin{array}{l}\text { プロック連結道路数が少な } \\
\text { W. }\end{array}$ \\
\hline & †道路との近按性 & & - & & $\begin{array}{l}\text { オ道路と倠れて位留する } \\
\text { フロックク }\end{array}$ & 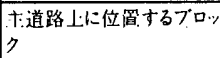 \\
\hline & 公園との隣接性 & $\bullet$ & & & 公園と隣演したブロック & 公園と隣接していないプロッ \\
\hline & 塨の高ざ & - & - & & 祝線の高さ $(1.5 \mathrm{~m})$ 以上: & 祝線の高ゴ $(1.5 \mathrm{~m})$ 以下 \\
\hline & 榐の特性 & & $\bullet$ & & $\begin{array}{l}\text { 四んでいる埸が閉銷的な } \\
\text { 壦合 }\end{array}$ & $\begin{array}{l}\text { 睤んでいる憬が開放的な } \\
\text { 场合 }\end{array}$ \\
\hline & 際接祝線 & & - & & $\begin{array}{l}\text { 隣から良く見る本が山来な } \\
\text { い配简 }\end{array}$ & $\begin{array}{l}\text { 隧から良く見る本が山来る } \\
\text { 配滥. }\end{array}$ \\
\hline 䓡 & 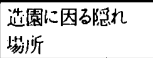 & & - & & 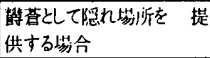 & 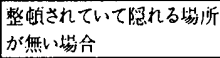 \\
\hline 党 & 建物形態 & - & - & & 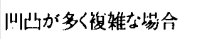 & |岀凹凸が無く単純な萮合 \\
\hline 連 & 建物の也彩 & & - & & $\begin{array}{l}\text { 建物の外臂色㹻が喑い } \\
\text { 㺃合 }\end{array}$ & $\begin{array}{l}\text { 建物の外臂色彩が明るい } \\
\text { 㘯合 }\end{array}$ \\
\hline 校 & 空の大きさ & $\bullet$ & - & & 空の大きさが大きい垗合 & 空の大ぎが小导い埸合 \\
\hline & 忩の湖数 & $\dot{\theta}$ & - & & 空の数が多い哕合 & 空の数が少い場命 \\
\hline by & 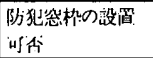 & - & & & 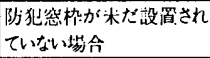 & $\begin{array}{l}\text { 防犯空机が設临された 㖴 } \\
\text { 合 }\end{array}$ \\
\hline$\sqrt{2}$ & 蒚の芜徵 & & & & $\begin{array}{l}\text { 富裕な家の㥞に見える 嵓 } \\
\text { 合 }\end{array}$ & 筫しい家の样見える 梤命 \\
\hline
\end{tabular}

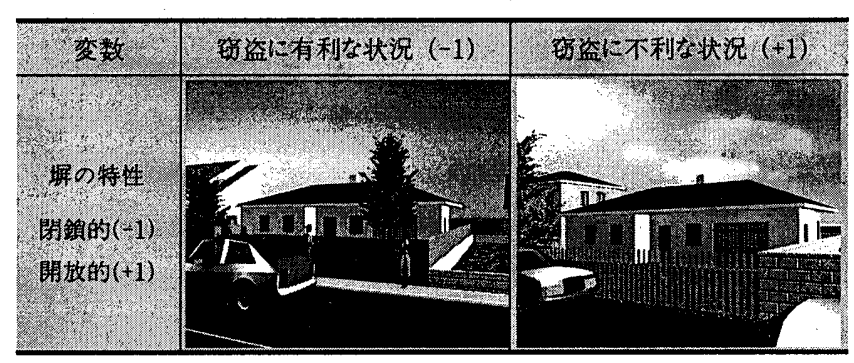

図4. シミュレーションモデルから分析変数が操作されたイメージ事例

\section{3. 実験対象及び実験の順序}

実験は、ソウルに在るK大学の工学部1学部の内、実験の参加を希望 する学生80名を対象とし、約一ヶ月わたりなされた。大多数が犯罪経験の ない大学生を対象に実験を遂行したのは、実際に起訴された铂盗犯を対 象に実験を遂行するのが現実的に難しいだけでなく、起訴された铅盜犯か ら得る情報が、代表性と信頼性を確信できないという多数の研究結果
(Cornish \& Clark, 1986;Bennett and Wright, 1984; Brantingham \& Brantingham,1993)を根拠とする。また、韓国 (犯罪白書、199 3）及び英国（British Crime Survey，1988)の犯罪統計に因れば、 苆盗犯罪の過半数以上が青少年に因って行われているため、一般人を対 象に実験を遂行するのが妥当性を持つことができる。

表2. 実験の段階別組合 及び 段階別サンプル数

\begin{tabular}{|c|c|c|}
\hline & (c) & 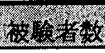 \\
\hline 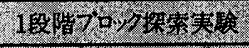 & 12個 ブロック & 80 名 \\
\hline \multirow{4}{*}{ 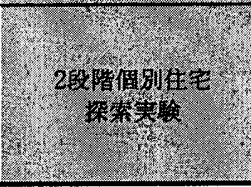 } & セット 1 (1,5,97゙ロックの内25個住宅) & 20名 \\
\hline & セット 2(2,6,10ブロックの内25個住宅) & 20名 \\
\hline & セット 3(3,7,117゙ロックの内30個住宅) & 20名 \\
\hline & セット 4(4,8,127゙ロックの内25個住宅) & 20名 \\
\hline
\end{tabular}

（1）実験1段階：ブロック探索過程

1段階の実験で、被験者は団地内の 12 個のブロック(図5参照)を定め られた順序により、動映像で体験し、動映像体験が終わった後に12個の ブロック中筇盗遂行に一番適するブロックを優先順位によって、3つ選定し 選定理由を簡単に記述するようにした。

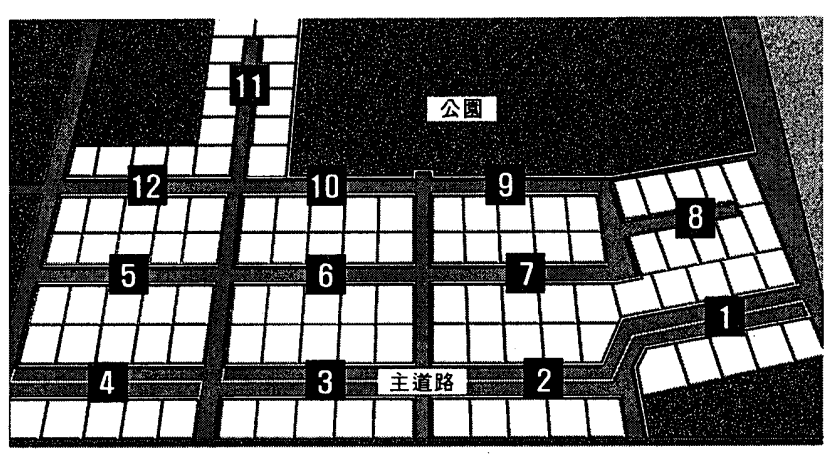

図5. 団地配置図

\section{（2）実験2段階：個別住宅探索過程}

2段階で被験者は、任意に割り振られた3個ブロックの動映像探索過程 を順次的に体験する事になる。一つのブロック体験が終った後実験対象 者はブロック内10戸の住宅(ブロック9・10は5戸で構成)中、筇盗を遂行 する為に最も適すると考えられる2戸の住宅(5戸で構成されたブロック9・10 では、10戸の住宅で構成された他のブロック選択機会を同等にする為に1 戸だけ選択するようにする。)を優先順位に依って記入し、各々の選定理 由を簡単に記入するようにした。

\section{4. 研究結果}

\section{1. ブロック特性と窃盗被害確率}

1段階ブロック探索実験で被験者が応答した各ブロック別锰盗遂行の 適合性を分析した結果骞盗遂行に一番適していると認識したブロックは主 道路から遠く離れた、突き少たりの路地であるブロック11で、19.86\%の一 番高い被害確率を表し、ブロック9、ブロック10、ブロック8の順に高い被 害確率を表した。此等のブロックは、皆公園と隣接し主道路から遠く離れ たブロックという共通した特性を持つ。反面被験者が窃盗を遂行するのに 一番不適合だと判断されるブロックは、団地中央に位置する7ブロックで、 $1.81 \%$ の一番低い被害確率を見せ、ブロック2、ブロック4、ブロック3の順 に低く表わされるが大部分の主道路上に位置するブロックであった。被験 者が応答した選定理由を内容分析(content analysis)を通じ危険性要因 
と容易性要因、孔て報償要因に分類した結果(表5参照) 総計340件の 応答で危険性要因が192件(56.5\%)、容易性要因が147件(43.2\%)で あった。一番高い被害確率を表したブロック11の場合、総84件の応答中 53件が危険性の要因に関するものであり、また31件の応答は容易性要因 に関するものと現れ、钫盗犯が犯罪対象のブロックを選定する際、容易性 要因よりは危険性要因をより考虑するという事を示している。容易性要因に 比べ危険性要因をより重要と考虑する傾向は、被害確率が高かったブロッ ク9、10、8に共通して現れた。ブロックの選定の具体的な理由を調べてみ れば「突き少たる路地に監視の視線が少ないため」，または「人の気配 がないため」、「向かい側の視線の㕌虑がないため」，「孤立されたブ ロックであり家具の数が少ないため」等で、発覚される危険性と関連した 要因がかなり多い数を占め、大部分が遠く、突き尖たりの路地や公園に 隣接していて、家具の数が少ないという特徵があるブロック11，9，10，8 が、何故違うブロックに比へて高い被害確率を表すのかを説明してくれる。

表3. ブロック別選定頻度及び铇盜被害確率

\begin{tabular}{|c|c|c|c|c|c|c|c|c|c|c|c|c|}
\hline 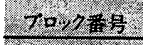 & Bl & $\mathrm{B} 2$ & B3. & B4: & B5. & $B 6$ & B7. & B8 & B9 & $B 10$ & B11 & B12 \\
\hline 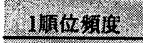 & 5 & 1 & 4 & 3 & 3 & 8 & 2 & 4 & 15 & 9 & 20. & 4 \\
\hline 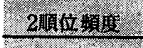 & 5 & 2 & 3 & 5 & 5 & 2 & 0 & 15 & 9 & 11 & 10 & 9 \\
\hline 3) & 6 & 5 & 4 & 2 & 5 & 4 & 2 & 10 & 7 & 7 & 12 & 11 \\
\hline 秷頛甠 & 16 & 8 & 11 & 10 & 13 & 14 & 4 & 29 & 31 & 27 & 42 & 24 \\
\hline 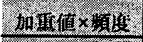 & 31 & 12 & 22 & 21 & 24 & 32 & 8 & 52 & 70 & 56 & 92 & 41 \\
\hline 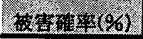 & 6.46 & 2.43 & 4.65 & 4.24 & 4.86 & 7.08 & 1.81 & 10.07 & 150 & 1153 & 19.86 & 8.1 \\
\hline
\end{tabular}

表4. ブロック及び個別住宅関連変数のt-test分析結果

\begin{tabular}{|c|c|c|c|c|}
\hline & 分析新数 & 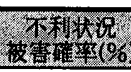 & 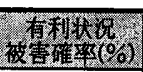 & 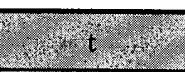 \\
\hline & 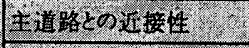 & 4.504 & 12.930 & -3.856 \\
\hline & 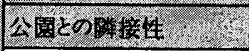 & 4.965 & 14.115 & $3.958^{\circ}$ \\
\hline & 連結道路数 & 10.640 & 6.140 & 1.338 \\
\hline & 塀の高さ & 10.139 & 12.473 & -1.485 \\
\hline & 嚗の特惟 & 8.965 & 13.461 & $2.998^{\circ}$ \\
\hline & 隣接視線 & 11.118 & 11.423 & -0.203 \\
\hline & 造園办的身边提供 & 9.451 & 13.082 & $2.365^{\circ}$ \\
\hline 㓢住宅 & 建物形管 & 9.606 & 18.082 & $3.702^{* *}$ \\
\hline & 建物の色彩 & 10.181 & 14.600 & 2.032 \\
\hline & 忩門の大きさ & 12.525 & 10.721 & 1.110 \\
\hline & 㥕門個数 & 11.154 & 11.494 & 0.213 \\
\hline & 防犯空枠設置与杏 & 12.198 & 10.419 & 1.128 \\
\hline & 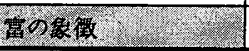 & 9.763 & 13.795 & $2.397^{2}$ \\
\hline
\end{tabular}

$* \mathrm{p}<0.05, * * \mathrm{p}<0.01$

分析変数が果して㙀盗犯の対象ブロック選定に影響を及ぼすかを見る 為に各変数別にモデルで設定された筀盗に不利な状況と有利な状況の間 に窃盗被害確率に有意な差異が有るかをt-testを通して、分析した(表4 参照)。t-test分析の結果、ブロック探索関連変数の内公園との隣接 性、主道路との距離はモデルで設定した窃盜に不利な状況と有利な状浣 間に攽盗被害確率で、統計的に有意な差異が有るものとして現れたが、 ブロック両端の連結道路の数は有意な差異が無いものとして現われた。こ うた分析結果は、公園と隣接したブロックは公園に身を隱す場所を提供 したり、公園を通した侵入または逃避が容易な為、公園から遠く離れたブ ロックに比べ被害確率が高く、主道路と近接したブロックの場合、多い交 通量による監視の目のがある為に被害確率が低いと既存研究(Molumb y、1976; Dietrick、1977；林と朴、1992)の結果と一致した。ブロック両 端の連結道路の数に従って、铅盗被害確率に差異が有るべきだとの研究
仮説は、十字路は、突き少りの袋路、L字形等の道路形態に比べてブ ロックと連結される道路数が多く、多様な逃走経路を提供する為に被害確 率が高く現われるだろうとの(朴、1995)容易性要因に基する仮説と連結道 路が多い程交通量が多くなり、監視の目が鋭くなる為、被害確率が低く 現われるだろうとの危険性要因に基する仮説の二つが提示された。 t-test 分析の結果は統計的に有意ではないが、連結道路の数が多いブロックで ある程、被害確率は低〈現われるブロックと連結道路の数は、容易性要 因よりは危険性要因が優先的に考慮されているという事を見せてくれる。連 結道路の数が少いブロックを選択した一部の応答者は、選択理由として 連結道路の数が少いブロックが、寧ろ警察出動を遅延させる効果が有る 為だと応答し、やはり容易性要因よりは危険性要因を主考虑事項としてい るのを見せてくれる。

\section{2 個別住宅の特性と空盗被害確率}

2段階実験で被験者の対象住宅選定理由を察して見ると伦険性要因と 容易性要因が総て697件の応答中、各々 360 件 (51.6\%)、308件 (44.2\%)と殆んど似た比率を占めて居り、報償要因は相対的に少い比率を 占めて居り、重要な役割を果していないと現している(表5参照)。

表5. 選択したブロック及び個別住宅の選定理由

\begin{tabular}{|c|c|c|c|c|c|c|}
\hline & \multicolumn{4}{|c|}{ 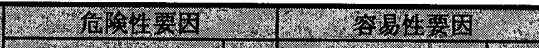 } & \multicolumn{2}{|c|}{ Hot } \\
\hline & 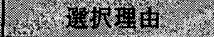 & 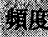 & 1.5. & 4 & 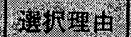 & 類鹿 \\
\hline \multirow{5}{*}{ 祖定理由 } & 通行星が多い(塔名性) & 33 & 逃走路が多い & 53 & 富裕に見える & 1 \\
\hline & 監祝の祝線が少ない & 140 & 侵入容易(公園隣接) & 83 & & \\
\hline & 警察巡察讙い & 12 & 仹宅密果(逃走容易) & 9 & & \\
\hline & 隐身処の提供 & 4 & 其他 & 2 & & \\
\hline & 其他 & 3 & & & & \\
\hline 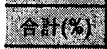 & \multicolumn{2}{|l|}{$192(565 \%)$} & \multicolumn{2}{|l|}{$147(13228)$} & \multicolumn{2}{|l|}{$103 \%$} \\
\hline \multirow{5}{*}{ 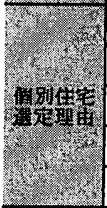 } & 造園が隐身処提供 & 85 & 䏚犯用空の未没誼 & 30 & 富衯に見える & 29 \\
\hline & 配置/形態が祝線遮断 & 48 & 体宅形態(単層, 叫凸) & 86 & & \\
\hline & 䍝で祝線遮断 & 94 & 低い挥の信人容易 & 84 & & \\
\hline & 監祝の祝線が少ない & 100 & 逃走及び侵人容易 & 87 & & \\
\hline & 忩門の大きさ & 33 & 其他 & 21 & & \\
\hline 合誥 $(\%)$ & \multicolumn{2}{|l|}{$360 .(51.6 \%)$} & \multicolumn{2}{|c|}{$308(44,2 \%)$} & \multicolumn{2}{|c|}{$29(4,2 \%)$} \\
\hline
\end{tabular}

被害確率が高い住宅の選定理由の中で、危険性要因に該当する応 答は大部分の監視機会と関連した物で「高い塀（94件）や、爰蒼とした 庭 (85件)」「凸凹が多い住宅の形態と配置(48件) 等に基づき、近 所の住民の監視の目が遮断されたり身を隠す場所を提供する事になる 為」という応答が大部分を占めた。反面、容易性要因に該当する応答 は大部分、侵入の容易性と関連した物で「榐が低く乗り越之易い」(84 件）、「凹凸が多くよじ登るのが容易な為」(86件)、「防犯用の空 の格子が設置されていないため侵入しやすい」(30件)等が主な応答で あった。

研究変数別に、モデルで設定した穷盗に不利な状況と有利な状況の 間に被害確率に有意な差があるかを見る為、t-testを実施した結果(表4 参照)2つの集団の間で一番はっきりとした差が目立つ変数は、住宅の形 態であった。又、塀の特性によっても有意な差が有る物として現れたが、 視覚的に開放的な塀は、閉鎖的な塀に比べてずつと低い铹盗被害確率を 示す物として現れた。これは、自然的な監視機会と関連した事として塀が 開放的な場合、道路や隣接住宅での視線のため忌避するからと判断され る。住宅の経済的な価值(富の象徵)に従った被害確率も、やはり有意な 差があるものと現れたが、裕福に見える住宅は筫困に見える住宅に比べ被 害確率が高かった。また喥蒼とした庭をもつ住宅は庭がうまく整頓された住 宅に比べ被害確率がより高く表れ、理由としては、大部分の被験者が 
「椥蒼とした庭が隣近所の監視の目を遮断したり隠れる場所を提供する 為」(85件)と応答し、庭は絶対的に伦険性要因として認識するものと示さ れた。一方、塀の高さは統計的に有意な差を見せなかったが、高い塀を 持った住宅集団が低い塀を持った住宅集団に比べ、多少の高い被害確 率を示した。理由として「高い塀が外部視線を遮断する事に依って、窃 盗に有利に作用する」との応答が 94 件、「低い垠が侵入、及び逃走に 容易である」との応答が 84 件となり窃盗犯の個人別特性(窃盗経験、身 体条件、性別等)に依って高い榐が究盜に不利な状況としても、或いは有 利な状況としても認識出来るという事を見せてくれる。

\section{5. 結論}

分析結果を要約すれば、ブロック探索過程では主道路との距離及 び、公園との隣接性という二つの変数、個別住宅の探索過程では建物 形態、塀の特性、富の象徵、庭の造りによった檃れ場等が対象物選定 と関連があるものとされた。又、ブロック探索では危険性要因が容易性要 因に比べ、優先的に考虑されるものとは別に、個別住宅探索過程では二 つの要因が皆類似した比重を持って考虑されるものと認められた。

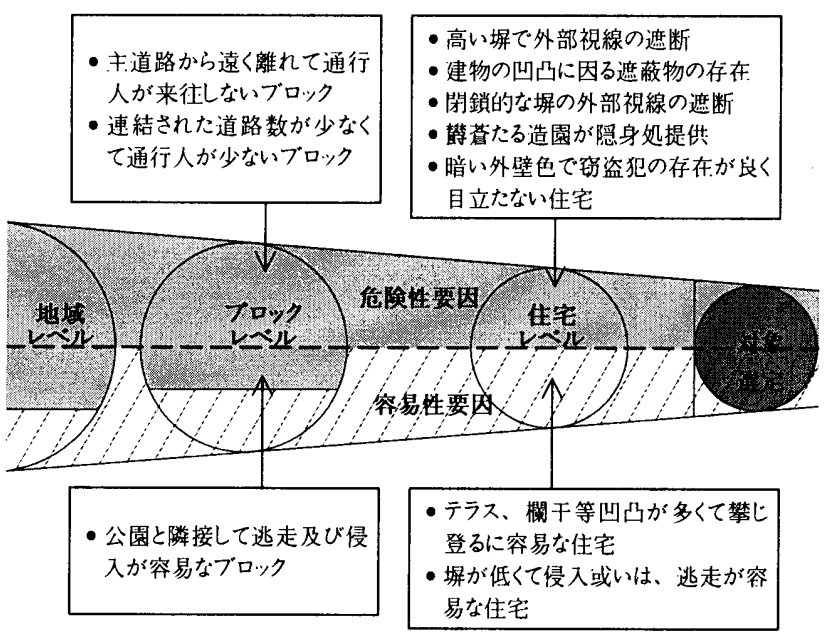

困6. 対象物選定で危険性要因と容易性要因の役割

たとえ統計的に有意と認められはしなかったとしても、铅盗犯の探索過 程に対する一部の結果は、既存研究の結果等、我々が常識的に考えて 来た犯罪の抑制要素や促進要素が実際とは異る点が有り得る事を暗示 寸る。従って高い塀が究盗予防に有利だとか、大きい空が窃盗予防に不 利だという事が一般的な常識だが本研究結果は、寧ろ小さい空を持った 住宅が窃盗により脆い可能性があり、窃盗犯の特性によっては高い塀が 必ず穷盗を抑制する要因というよりも反って促進する要因としても作用する 事もあると見れる。しかし、本研究の被験者が穷盗犯を対象とせず一般 人を対象としたという点で、此の様な研究結果の妥少性に対しては追って 持続的な研究を通して検証するべき問題であると判断される。

一方、本研究で使用されたシミュレーションモデルは既存研究で使用さ れた環境シミュレーション方式に比へて多くの長所を持っているが、未だ改 善しなければならない様々な制約点を持っている。先ず、技術的問題と余 ク多くの製作費用の為完璧な双方向的探索過程を、存分にシミュレーショ ン化出来ないままでいる。次に、モデルに使用された一部変数を被験者 が認識出来ないでその影響が過小評価された可能性がある。即ち、防 犯設備補完等は警察に依って断え間無〈強調される予防対策であり、 徉ってその効果が強力であるべきと予測したが本研究ではきほど影響力が 有る変数と立証されなかった。しかし、此の様な理由では防犯空枠の存
在可否自体がコンピューター画面で容易に実験対象者達に認識されな かった可能性が存在し、此の様な点はシミュレーションモデルが持つ技術 的制約の中の一つとして指摘される。最後にモデル自体が昼間の状況を シミュレーションしたもので、昼間に発生する钬盗が過半数を過ぎるのは研 究結果を総ての状況に一般化し得ないという点も限界だとして指摘される。 しかし、殆んど知られなかった探索過程、特に窃盜に適合した住宅に対す る「一般的イメージ」(テンプレイト)を構成する要因等の中で一部が明ら かにされ、或る環境特性が窃盜の抑制要因或いは促進要因として認識さ れるかを把握したのは、この後、住宅の防犯設計指針の設定とか警察の 究盗予防対策を樹立する上で重要な基礎資料構築の効果が有ると思わ れる。また前に述へた技術的な問題点が補完されなければならないといっ た課題を抱えているが、動映像を利用したシミュレーションモデル開発を通 し、既存の方法論的問題点を一部でも改善したことは、本研究の重要な 奇与であると判断される。従って、今後窃盗犯の微視的な意思決定に関 する研究が、异らに活溌になされ得るものと期待される。

注

1）容易性要因は対象物にとんなに容易に侵入し逃走する事が出来るかという程度を 意味するもので、幄の高さとか忩の大きさ、忩や門の保安状熊、多様な逃走経路、 空地や野山等との隣接性等が合まれる。

2）出来る限り伦険を避けようとするのは、一般的に合理的行動の特性である。伦険 性要因とは、铂盗行為中に見つかるか、若しくは速捕跒可能性と関連した要因 で、隣りの住比や步行者に依った自然的な監視機会(surveillance)、体を嬡す事の 出来る場所の存在可否、警察の巡察の頻度等が含まれる。

3）建物形態の被䧴さ、外壁の色彩の暗さ、隣接住宅からの視線の接近性、住宅 の経済的な侕値等は客観的に測定しにくいため、建筑を専攻した大学院生 3 人に各々 の住宅を評体きせて、その平均值を持って測定值で使用した。

4）特定ブロックを体験した総20名の実験対象者達が、各自のブロックに対し優先脽 位通りに2個の住宅を選択するよう仕組んだので、20名の対象者達がやり得る応答 の頻度数は総 40 回である。この中で1順位に選択された場合は、加重値を1.0にして2 順位に選択された場合は加重值を0.5を与えたので、䒠際可能な応答の頻度数は総 30回である。この中で万がーunit 1が1順位で5番、2順位で4番選択されたら铅盗 被害確率は $[(5 \times 1.0)+(4 \times 0.5)] / 30 \times 100=23.3(\%)$ で計筧する事が出来る。

\section{参考文献}

1. 任勝柣、朴昌錫：犯罪予防の為の住居団地設計基準に関する研究、大 韓建築学会論文集、Vol.8、No.10、1992.10

2. Bennet、 T. : Burglars Choice of Targets, In K. Heal and G. Laycock (eds.) Situational Crime Prevention : From Theory into Practice. London : HMSO、 1986

3. Brantingham、 P.J and Brantingham、 P.L. : A Theoretical Model of Crime Site Selection. In M.D. Krohn and D.L.Akers(Eds.) Crime. Law and Sanctions : Theoretical Perspectives. Sage Publications : Beverley Hills, 1978

4. Dietrick, B. : The Environment and Burglary Victimization in a Metropolitan Suburb. Paper presented to the annual meeting of the American Society of Criminology、Atlanta、 GA. 、 1977

5. Molumby, T. : Patterns of Crime in a University Housing Project. American Behavioral Scientist. Vol.20、1976

6. Rengert、 G. and Wasilchick、 J. : Space、Time and Crime : Ethnographic Insights into Residential Burglary、 U.S. Department of Justice、 Final Report, 1988

7. Taylor、 M. and Nee、 C. : The Role of Cues in Simulated residential Burglary : A Preliminary Investigation. British Journal of Criminology, Vol.28、 No.3、1988

8. Walsh、 D. : Victim Selection Procedures Among Economic Criminals : Tjhe Rational Choice Perspective、 In D.B. Cornish and R.V. Clarke, The Reasoning Criminal. Springer Verlag : New Yor k. 1988

（2003年 3 月 3 日原稿受理，2004年 1 月 22 日採用決定 $)$ 